\title{
THE OCCURRENCE OF TETANY DURING ANAESTHESIA
}

\author{
D. V. Catton, M.D., F.R.C.P.(c), ANd R. A. Browne, M.B., F.F.A.R.c.s. ${ }^{\circ}$
}

THE INCREASING USE of mechanical ventilators during anaesthesia to obtain hyperventilation has brought about the recognition of several complications such as prolonged apnoea ${ }^{1}$ and diminished cerebral blood flow. ${ }^{2}$ The occurrence of tetany is usually not considered, and it was only the recent paper by Conway and Hoffman $^{3}$ which prompted us to report the following two cases.

\section{Case Reports}

\section{Case 1}

A 23-year-old white female (height 62 inches, weight $63.2 \mathrm{~kg}$.) presented with a recent, rapidly-enlarging abdominal mass. Her general health was excellent and past history and physical examination non-contributory.

Preoperative sedation for the proposed laparotomy consisted of meperidine $75 \mathrm{mg}$. and atropine $0.6 \mathrm{mg}$. one hour preoperatively. An uneventful induction was carried out with thiopentone, succinylcholine, ventilation, intubation sequence.

Maintenance of anaesthesia through the cuffed endotracheal tube was with $\mathrm{N}_{2} \mathrm{O}\left(3 \mathrm{~L} . / \mathrm{min}\right.$.), $\mathrm{O}_{2}(2 \mathrm{~L} . / \mathrm{min}$.), plus halothane 1.0 per cent delivered through a Fluotec Mark 2 vaporizer outside the circle $\mathrm{CO}_{2}$ absorber circuit. Respirations were controlled with an Air Shields Ventimeter and succinylcholine infusion 0.1 per cent, and the operative procedure of multiple myomectomies and uterine supension carried out.

One hour and 50 minutes after induction, carpal spasm (Trousseau's Sign) ${ }^{4}$ appeared in the left hand (sphygmomanometer was applied over left upper arm). The wrist was flexed to a right angle. The fingers were flexed at the metacarpophalangeal joints and extended at the interphalangeal joints. The thumb and fingers were adducted. The right arm was tucked in at the side and not visualized. Tapping over the facial nerve produced a Chvostek's sign. The abdominal muscles appeared relaxed. The blood pressure and pulse were both at pre-induction levels and the patient had received two units of whole blood to replace a persistent ooze. The $\mathrm{CO}_{2}$ absorber was warm and not discoloured. Succinylcholine 0.1 per cent to a total of $200 \mathrm{mg}$. had been given. The ventilator was delivering a respiratory minute volume of $12.0 \mathrm{~L} . / \mathrm{min}$. (tidal volume 600 c.c. and a rate of 20 per minute).

Analysis of blood from a brachial artery puncture revealed a $\mathrm{pH}$ of $7.57, \mathrm{~Pa}_{\mathrm{CO}_{2}}$ $20 \mathrm{~mm}$. Hg, Sa $\mathrm{O}_{2} 99$ per cent, base excess $3 \mathrm{mEq}$./L., actual bicarbonate $17 \mathrm{mEq} . /$ L., standard bicarbonate $22 \mathrm{mEq} . / \mathrm{L}$, and serum calcium $6.0 \mathrm{mg}$. per cent (normal 8.8-10.6 mg. per cent).

-Department of Anaesthesia, Hamilton Civic Hospitals.

Can. Anaes. Soc. J., vol. 14, no. 6, November, 1967 
The $\mathrm{CO}_{2}$ absorber was excluded from the circuit and ventilation volume reduced. Within ten minutes the carpal spasm was gone. Calcium gluconate 1.0 gm. was given intravenously and within a further five minutes all signs of tetany were gone.

No difficulty or undue delay was encountered in re-starting spontaneous respirations. The patient left the operating room 45 minutes after tetany was recognized, breathing spontaneously and adequately.

\section{Case 2}

A 40-year-old white female, $51 \mathrm{~kg}$. in weight, was presented for middle ear surgery. Her preoperative history and physical findings were negative, except for chronic ear disease.

Preoperative sedation consisted of promethazine $40 \mathrm{mg}$. and atropine $0.6 \mathrm{mg}$. one hour preoperatively. An uneventful induction was carried out with thiopentone, succinylcholine, ventilation, intubation sequence. Maintenance of anaesthesia through the cuffed endotracheal tube was with $\mathrm{N}_{2} \mathrm{O}(3 \mathrm{~L} . / \mathrm{min}),. \mathrm{O}_{2}(3 \mathrm{~L} . / \mathrm{min}$.), plus methoxyflurane 1.5 per cent delivered by a Pentec vaporizer outside the circle $\mathrm{CO}_{2}$ absorber circuit. In order to help reduce bleeding, it was decided to hyperventilate the patient manually and allow a degree of hypotension to develop.

Twenty minutes after induction, a facial twitch was noted during preparation of skin around the ear. Forty-five minutes after induction the classical signs of tetany appeared in the left hand along with facial twitching. The blood pressure was $88 \mathrm{~mm}$. Hg systolic ( $110 \mathrm{~mm}$. preoperatively) and pulse rate 66 per minute (84 per minute preoperatively). Tidal volume was 700 c.c., with a respiratory rate of 16 per minute, delivering a respiratory minute volume of $11.2 \mathrm{~L} . / \mathrm{min}$.

Puncture of the left radial artery gave a $\mathrm{pH}$ of $7.47, \mathrm{~Pa}_{\mathrm{CO}_{2}} 32 \mathrm{~mm} . \mathrm{Hg}$, $\mathrm{Sa}_{\mathrm{O}_{2}} 100$ per cent, base excess $+1 \mathrm{mEq} . / \mathrm{L}$., actual bicarbonate $23 \mathrm{mEq} . / \mathrm{L}$, standard bicarbonate $24 \mathrm{mEq} . / \mathrm{L}$., and serum calcium $9.3 \mathrm{mg}$. per cent.

The $\mathrm{CO}_{2}$ absorber was excluded from the circuit and ventilation volume reduced. Calcium gluconate $1.0 \mathrm{gm}$. was administered intravenously. Forty-five minutes later all signs of tetany were gone. No delay in onset of spontaneous respirations or return of consciousness was experienced.

\section{DisCussion}

The substitution of hyperventilation for potent anaesthetic drugs has many advantages. It is, above all, controllable, and since $\mathrm{CO}_{2}$ is a normal metabolite, recovery from it is rapid. ${ }^{5}$

Chvostek's sign and Trousseau's sign illustrate the unstable polarization of nerve fibres. Hyperventilation is believed to cause a fall in only the ionized portion of serum calcium and may not be reflected by a fall in the total serum calcium. $^{\mathrm{B}}$

George et al..$^{7,8}$ reported a series of fifteen voluntary hyperventilating subjects who intentionally developed tetany. All but one of the subjects had an increase in total serum calcium during tetany (average $0.65 \mathrm{mg}$.), and all showed a fall in 
serum phosphate. The authors suggest that hyperventilation, by decreasing the ionized serum calcium to tetany levels, may cause the parathyroids to release an increased amount of hormone. This would account for a rise in total serum calcium and a fall in serum phosphate. A major portion of the inorganic phosphate lost from the serum with hyperventilation may be accounted for by increased phosphate esters within the red blood cell. This constant fall in serum phosphate has been confirmed by others in conscious subjects. ${ }^{9}$

In the first case report, the gross hyperventilation accomplished. would be expected to lead to a severe respiratory alkalosis as evidenced by the blood gas studies. It was interesting that abdominal relaxation appeared adequate in spite of facial and peripheral signs of tetany. The ventilation of the second patient, while intentionally exceeding physiological needs, would today hardly be considered excessive. Scott and Cantor ${ }^{10}$ have shown that people who hyperventilate have unusual reactivity to supervised voluntary hyperventilation. This led Okel and Hurst ${ }^{11}$ to suggest that the unusual susceptibility to tetany of these subjects is related to a similar situation in which chronic respiratory alkalosis is maintained in spite of seemingly normal respiration.

A few deep breaths will then be sufficient to produce tetanic symptoms. It may well be that the hyperventilation between paralysis and intubation was sufficient to precipitate tetany in the second case, as a facial twitch was noted during the skin preparation.

It is surprising that with the common practice of hyperventilation during anaesthesia, the complication of alkalotic tetany is not more frequently encountered.

\section{SUMMARY}

Two cases of tetany occurring during anaesthesia are presented, with blood gas studies confirming the degree of hyperventilation alkalosis. The pertinent literature is reviewed.

\section{RÉSUMÉ}

L'usage croissant de ventilateurs mécaniques au cours de l'anesthésie pour produire de l'hyperventilation a participé à dépister plusieurs complications telles l'apnée prolongée et le débit sanguin cérébral diminué. D'habitude l'on ne mentionne pas l'apparition de la tétanie. Nous présentons deux cas de tétanie au cours de l'hyperventilation où des études du sang artériel ont confirmé une alcalose prononcée par hyperventilation. Dans chacun de ces cas, le traitement a consisté à enlever du circuit la chaux sodée et à diminuer le volume minute de la ventilation.

\section{REFERENCES}

1. Wylie, W. D. \& Churchill-Davidson, H. C. A Practice of Anaesthesia. 2nd ed., Chicago: Year Book Medical Publishers (1966).

2. KetY, S. S. \& Schmmт, C. F. The Effect of Active and Passive Hyperventilation on Cerebral Blood Flow. J. Clin. Invest. 25: 107 (1946). 
3. Conway, J. C. \& Hoffman, R. J. Tetany during Deep Halothane Anaesthesia. Anaesthesia. 22 (1967).

4. WRight, S. Applied Physiology. 10th ed., London: Oxford University Press (1961).

5. Geddes, J. C. \& GraY, T. C. Hyperventilation for the Maintenance of Anaesthesia. Lancet. 2: 4 (1959).

6. Harrison, T. R. Principles of Internal Medicine. 5th ed., New York: McGraw-Hill (1966).

7. Geonge, W. K.; Smith, J. P.; Geonge, W. D.; Bampd, E. E.; Gordon, F. T.; \& Fisher, R. G. Hyperventilation and Hypocalcemia. New England J. M. 268: 17 (1963).

8. Geonge, W. K. et al. Changes in Serum Calcium, Serum Phosphate and Red-cell Phosphate During Hyperventilation. New England J. M. 270: 14 ( 1964).

9. Saltzman, H. A.; Heyman, A.; \& Sieter, H. O. Correlation of Clinical and Physiologic Manifestations of Sustained Hyperventilation. New England J. Med. 268: 26 (1963).

10. Scott, J. W. \& Cantor, M. M. Spontaneous Hyperventilation Tetany. Am. J. Med. Sc. 186: 509 (1933).

11. Oket, B. B. \& Hurst, J. W. Prolonged Hyperventilation in Man. Arch. Int. Med. 108: (1961). 